\title{
Serum Concentration of 24, 25-Dihydroxyvitamin $D$ in Normal Children and in Children with Rickets
}

\author{
THI MINH NGUYEN, H. GUILLOZO, M. GARABEDIAN, E. MALLET, AND S. BALSAN
}

Laboratoire des Tissus Calcifiés (CNRS ER 126 and INSERM U.30) Hôpital des Enfants Malades, Paris, France and Unité d'Explorations Fonctionnelles, Hopital Charles Nicolles, Rouen, France

\begin{abstract}
Summary
The present method for the measurement of 24,25-dihydroxyvitamin D $\left(24,25-(\mathrm{OH})_{2} \mathrm{D}\right)$ in serum associates the highly sensitive competitive protein binding assay of Preece et al. and a doublestep chromatography of the serum lipid extract (Sephadex LH 20 column and high pressure liquid chromatograph). With this assay, values observed in 16 normal children, 10 adolescents and 5 neonates, were not significantly different from those found in 14 normal adults $\left(25-(\mathrm{OH}) \mathrm{D}: 20 \pm 7.4 \mathrm{ng} / \mathrm{ml}, 24,25-(\mathrm{OH})_{2} \mathrm{D}: 1.4 \pm\right.$ $0.8 \mathrm{ng} / \mathrm{ml})$. No correlation was found between $25-(\mathrm{OH}) \mathrm{D}$ and 24,25- $(\mathrm{OH})_{2}$ D serum concentrations. Measurements of 25-(OH)D and $24,25-(\mathrm{OH})_{2} \mathrm{D}$ serum concentrations in some pathologic states demonstrated the existence of a 25-(OH)D-24-hydroxylase in children with three types of vitamin $D$ resistant rickets (hereditary hypophosphatemia, pseudodeficiency rickets, and vitamin D resistance associated with Recklinghausen's neurofibromatosis). Finally, results observed during vitamin $D$ administration suggest a regulation of the $24,25-(\mathrm{OH})_{2}$ D concentration in human serum: 1 ) $24,25-(\mathrm{OH})_{2} \mathrm{D}$ serum concentration increased after vitamin $D$ administration, yet it was not found higher in a 3-wk-old child with vitamin $\mathrm{D}_{2}$ intoxication (25-(OH)D: $900 \mathrm{ng} / \mathrm{ml}, 24,25-(\mathrm{OH})_{2} \mathrm{D}: 6$ $\mathrm{ng} / \mathrm{ml}$ ) than in three children with vitamin $D$ deficiency rickets in the 2 nd wk after administration of vitamin $D_{2}$ and calcium (25(OH)D: $25.5 \pm 9.2 \mathrm{ng} / \mathrm{ml}, 24,25-(\mathrm{OH})_{2} \mathrm{D}: 13.4 \pm 3.7 \mathrm{ng} / \mathrm{ml}$; 2) In a child with pseudodeficiency rickets, $24,25-(\mathrm{OH})_{2} \mathrm{D}$ concentrations were found elevated before treatment. They decreased to normal values during treatment with $1 \alpha-(\mathrm{OH})$ cholecalciferol, whereas $25-(\mathrm{OH}) \mathrm{D}$ concentrations were not significantly different before and after treatment.
\end{abstract}

\section{Speculation}

Development of methods for the measurement of $24,25-(\mathrm{OH})_{2} \mathrm{D}$ concentration in serum should provide valuable informations for a better understanding of vitamin D metabolism in physiologic and pathologic states in children.

One of the polar metabolites of 25-hydroxyvitamin $D_{3}$ (25$\left.(\mathrm{OH}) \mathrm{D}_{3}\right)$, namely 24,25-dihydroxyvitamin $\mathrm{D}_{3}\left(24,25-(\mathrm{OH})_{2} \mathrm{D}_{3}\right)$ was first identified in 1973 (5). This metabolite is quantitatively the main $25-(\mathrm{OH}) \mathrm{D}_{3}$ dihydroxyderivative found in the serum of normal animals $(1,3)$ and of normal human subjects $(6)$. Its significance in vitamin $D$ physiology is not clear $(2,3)$. Methods for the measurement of $24,25-(\mathrm{OH})_{2} \mathrm{D}$ concentrations in human serum have been recently developed $(4,8,10-12)$. The data obtained with these technics may help for a better understanding of the role of this metabolite. Results published so far concern mainly adults and, to our knowledge, only one investigation on serum $24,25-(\mathrm{OH})_{2} \mathrm{D}_{3}$ concentrations in neonates, children, and adolescents, has been reported (11). In 1976, an assay for $24,25-$ $(\mathrm{OH})_{2} \mathrm{D}$ measurement in lipid extracts of serum was developed in our laboratory. It includes a chromatography on Sephadex LH 20 column, a further purification step using a high pressure liquid chromatographic system and a competitive protein binding assay.
The present paper describes the method of $24,25-(\mathrm{OH})_{2} \mathrm{D}$ measurement in serum and reports the results obtained in normal children as compared to normal adults; in children with vitamin $D$ deficiency or vitamin $D$ resistant rickets; and in one child intoxicated with ergocalciferol.

\section{MATERIAL AND METHODS}

VITAMIN D METABOLITES

$\left[26,27-{ }^{3} \mathrm{H}\right] 25-(\mathrm{OH}) \mathrm{D}_{3}$ was purchased from the radiochemical Centre Amersham, Buckinghamshire, England (specific activity 11.7 or $12.1 \mathrm{Ci} / \mathrm{mmole}$ ).

$\left[26,27-{ }^{3} \mathrm{H}\right] 24,25-(\mathrm{OH})_{2} \mathrm{D}_{3}$ was obtained from in vitro incubations of prepubertal rabbit kidney homogenates with tritiated 25$(\mathrm{OH}) \mathrm{D}_{3}$, using the technique described for the production of $1,25-$ $(\mathrm{OH})_{2} \mathrm{D}_{3}$ in chick kidney homogenates (7). After methanol-chloroform extraction of the kidney tissue, the chloroform phase was chromatographed on a $2 \times 60 \mathrm{~cm}$ Sephadex LH 20 column equilibrated with chloroform-hexane 65:35 (v/v). 24,25-(OH ${ }_{2} \mathrm{D}_{3}$ was then chromatographed on a high pressure liquid chromatograph as described later in this paper. Periodate sensitivity of ${ }^{3} \mathrm{H}$ $24,25-(\mathrm{OH})_{2} \mathrm{D}_{3}$ was verified before its use.

$25-(\mathrm{OH}) \mathrm{D}_{3}$ was a gift from Roussel Laboratory, Paris, France and $24 \mathrm{R}, 25-(\mathrm{OH})_{2} \mathrm{D}_{3}$ a gift from Dr. Uskokovic, Hoffman-La Roche, Nutley, New Jersey. Both vitamin D metabolites were stored at $-20^{\circ} \mathrm{C}$ in ethanol.

\section{BINDING PROTEIN}

Weanling rats were kept in a dark room and raised on a vitamin $\mathrm{D}$ deficient diet containing $0.47 \%$ calcium and $0.3 \%$ phosphorus. After 4-6 wk, rats were sacrificed by decapitation, the serum was collected and frozen in $10 \mu \mathrm{l}$ aliquots at $-20^{\circ} \mathrm{C}$. A $1 / 20.000(\mathrm{v} / \mathrm{v})$ solution of this D-deficient rats serum in barbital acetate buffer pH 8.6 was used for the assays (9).

\section{SERA EXTRACTION AND CHROMATOGRAPHY}

Five hundred dpm of ${ }^{3} \mathrm{H}-25-(\mathrm{OH}) \mathrm{D}_{3}$ and $500 \mathrm{dpm}$ of ${ }^{3} \mathrm{H}-24,25$ $(\mathrm{OH})_{2} \mathrm{D}_{3}$ were added to $2 \mathrm{ml}$ of serum samples before their extraction. After $1 / 2 \mathrm{hr}$ at room temperature, chloroform-methanol extraction was performed as described by Preece et al. (9). The lipid extract was dissolved in $0.3 \mathrm{ml}$ of 50:50 chloroform-n hexane and chromatographed on a Sephadex LH 20 column $185 \times 5 \mathrm{~mm}$ equilibrated with the same solvent mixture. Thirty fractions of 1 $\mathrm{ml}$ were collected. A $0.2 \mathrm{ml}$ aliquot of each fraction was dried down and the radioactivity counted in $10 \mathrm{ml}$ of counting solution ( $5 \mathrm{~g}$ of PPO and $0.1 \mathrm{~g}$ of dimethyl POPOP/liter of toluene). Fractions in the ${ }^{3} \mathrm{H}-25-(\mathrm{OH}) \mathrm{D}_{3}$ region $(2-5 \mathrm{ml})$ and in the ${ }^{3} \mathrm{H}$ $24,25-(\mathrm{OH})_{2} \mathrm{D}_{3}$ region $(7-13 \mathrm{ml})$ were pooled separately and dried down. The fraction containing $25-(\mathrm{OH}) \mathrm{D}_{3}$ was applied on a silicic acid column to separate $25-(\mathrm{OH}) \mathrm{D}_{3}$ from vitamin $\mathrm{D}$ and from metabolites less polar than $25-(\mathrm{OH}) \mathrm{D}_{3}(9)$. The $24,25-(\mathrm{OH})_{2} \mathrm{D}_{3}$ fraction was dissolved in $0.1 \mathrm{ml}$ ethanol and injected in a high pressure chromatograph (Waters Associates, Milford, Massachu- 
setts 01757 , USA) equipped with a solvent delivery system model $6000 \mathrm{~A}$ and a sample injector model V6K, fitted with a $4 \mathrm{~mm} \mathrm{I.D.}$ $\times 30 \mathrm{~cm} \mu$ Bondapak $C_{18}$ column. A linear gradient from $50-100 \%$ methanol in water was used as solvent $(2.5 \% \mathrm{v} / \mathrm{v}$ per min) with a flow rate of $3 \mathrm{ml} / \mathrm{min}$. Six $\mathrm{ml}$ fractions of the effluent were collected. An aliquot $(0.5 \mathrm{ml})$ of each fraction was counted in 10 $\mathrm{ml}$ Instagel solution. The $24,25-(\mathrm{OH})_{2} \mathrm{D}_{3}$ region from high pressure liquid chromatography and the $25-(\mathrm{OH}) \mathrm{D}_{3}$ region from silicic acid chromatography were dried down and dissolved in $2 \mathrm{ml}$ ethanol. An aliquot of each of the final solutions was counted in order to measure the total recovery after the extraction and chromatographic procedures. Recovery was calculated as the ratio of the radioactivity present in the $2 \mathrm{ml}$ ethanol solution, to the radioactivity added to the serum sample before the extraction. Mean percent of recovery for the dosages of 78 different blood samples was $73.1 \pm 3.4$ for $25-(\mathrm{OH}) \mathrm{D}$ and $53.4 \pm 1.3$ for $24,25-(\mathrm{OH})_{2} \mathrm{D}$.

The association of Sephadex LH 20 and high pressure liquid chromatographies allows a good separation of $24,25-(\mathrm{OH})_{2} \mathrm{D}_{3}$ from $25-(\mathrm{OH}) \mathrm{D}_{3}$ and $1,25-(\mathrm{OH})_{2} \mathrm{D}_{3}$, as verified with tritiated metabolites. Synthetic metabolites of ergocalciferol were not available to investigate the ability of the chromatographic system to resolve vitamin $D_{2}$ and $D_{3}$ metabolites. Due to the size of the fractions isolated, it is most likely that $25-(\mathrm{OH}) \mathrm{D}$ and $24,25-$ $(\mathrm{OH})_{2} \mathrm{D}$ fractions contained the cholecalciferol and the ergocalciferol metabolites. Serum values are therefore expressed as $\mathrm{ng} / \mathrm{ml}$ of $25-(\mathrm{OH}) \mathrm{D}$ and $24,25-(\mathrm{OH})_{2} \mathrm{D}$.

\section{5-(OH)D COMPETITIVE BINDING ASSAY}

25- $(\mathrm{OH}) \mathrm{D}$ concentration was estimated with the assay described by Preece et al. (9). The high sensitivity of this assay allows the measurement of $25-(\mathrm{OH}) \mathrm{D}$ concentrations as low as $0.5 \mathrm{ng} / \mathrm{ml}$ of serum ( 0.02 pmole per incubation tube).

\section{4,25-(OH $)_{2}$ D COMPETITIVE BINDING ASSAY}

It has been shown that $24,25-(\mathrm{OH})_{2} \mathrm{D}_{3}$ has the same affinity as $25-(\mathrm{OH}) \mathrm{D}_{3}$ for the $25-(\mathrm{OH}) \mathrm{D}$ rat serum binding protein $(4,8,10$, 11). In our hands also, synthetic $24,25-(\mathrm{OH})_{2} \mathrm{D}_{3}$ was found as effective as $25-(\mathrm{OH}) \mathrm{D}_{3}$ in displacing ${ }^{3} \mathrm{H}-25-(\mathrm{OH}) \mathrm{D}_{3}$ from its binding to the $\mathrm{D}$-deficient rat serum protein. The $24,25-(\mathrm{OH})_{2} \mathrm{D}$ concentration in serum was therefore measured with the 25-(OH)D competitive binding assay system i.e., using as a standard curve, the displacement of ${ }^{3} \mathrm{H}-25-(\mathrm{OH}) \mathrm{D}_{3}$.

One serum was extracted ten times and each of the ten extractions was assayed twice for vitamin $D$ metabolites. Within assay variations were, respectively, $9.3 \%$ for $25-(\mathrm{OH}) \mathrm{D}(11.8 \pm 1.1 \mathrm{ng} /$ $\mathrm{ml})$ and $10.4 \%$ for $24,25-(\mathrm{OH})_{2} \mathrm{D}(2.6 \pm 0.27 \mathrm{ng} / \mathrm{ml})$.

\section{RESULTS \\ NORMAL SUBJECTS}

Serum $25-(\mathrm{OH}) \mathrm{D}$ and $24,25-(\mathrm{OH})_{2} \mathrm{D}$ concentrations were measured in 5 neonates, 16 children, and 10 adolescents with no alteration in phosphorus and/or calcium metabolism and no known renal, intestinal, or endocrine diseases. The values observed in these young subjects were compared to those found in 14 normal adults, aged 18-50 yr (Table 1). All samples were collected randomly throughout the year 1976 .

In normal adults, serum concentrations of $25-(\mathrm{OH}) \mathrm{D}$ and 24,25 $(\mathrm{OH})_{2} \mathrm{D}$ (mean $\pm 1 \mathrm{SD}$ ) were $20 \pm 7.4$ and $1.4 \pm 0.8 \mathrm{ng} / \mathrm{ml}$, respectively. The concentrations of these metabolites (mean \pm 1 SD) in children and adolescents were not significantly different from the values found in adults. In the five neonates studied before the 6th day of life neither $25-(\mathrm{OH}) \mathrm{D}$ concentrations nor $24,25-(\mathrm{OH})_{2} \mathrm{D}$ concentrations were statistically different from the values found in older children or in adults.

When all the data were pooled and analyzed according to the seasonal period of sampling (Table 1), lower concentrations of serum 25-(OH)D were noted during the winter and spring 1976. These low concentrations in serum $25-(\mathrm{OH}) \mathrm{D}$ were associated with higher concentrations of $24,25-(\mathrm{OH})_{2} \mathrm{D}$. However, none of these differences are statistically significant, presumably because of the small number of subjects studied in each season.

The analysis of the $25-(\mathrm{OH}) \mathrm{D}$ and $24,25-(\mathrm{OH})_{2} \mathrm{D}$ serum values for the whole group of normal subjects studied did not demonstrate a positive correlation between serum concentrations of $24,25-(\mathrm{OH})_{2} \mathrm{D}$ and $25-(\mathrm{OH}) \mathrm{D}$ (Fig. 1). It is to be noted that the seven highest values of $24,25-(\mathrm{OH})_{2} \mathrm{D}$ serum concentrations were found in subjects with low $25-(\mathrm{OH}) \mathrm{D}$ serum concentrations (lower or equal to $12 \mathrm{ng} / \mathrm{ml}$ ).

\section{VITAMIN D-DEFICIENCY RICKETS}

Serum 25-(OH)D and $24,25-(\mathrm{OH})_{2} \mathrm{D}$ concentrations were measured in three children (aged 14-18 months) with overt radiologic signs of rickets increased serum alkaline phosphatase activities (respectively, 2470,1850 , and $1000 \mathrm{mU} / \mathrm{ml}$ of serum with normal values from $112-696 \mathrm{mU} / \mathrm{ml}$ ), low serum calcium concentrations (respectively, $8.0,7.8$, and $8.8 \mathrm{mg} / 100 \mathrm{ml}$ ) and low serum phosphorus concentrations (respectively, $4.0,3.1$, and $2.7 \mathrm{mg} / 100 \mathrm{ml}$ ). Blood samples for vitamin D measurements could only be obtained after 1 wk of hospitalisation and after the start of oral calcium supplementation (180-360 mg/d). At that time, 25-(OH)D and $24,25-(\mathrm{OH})_{2} \mathrm{D}$ concentrations were low, but not significantly different from the values found in normal children (Table 2). During the first 2 weeks after one im injection of $5 \mathrm{mg}$ of vitamin $\mathrm{D}_{2}$, the measurement of vitamin $\mathrm{D}$ metabolites showed a slight increase (basal value $\times 2.6$ ) in serum $25-(\mathrm{OH}) \mathrm{D}$ concentration contrasting with a rapid and marked increase (basal value $\times 33$ )

Table 1. Serum 25-(OH)D and 24,25-(OH $)_{2} D$ concentrations $(\mathrm{ng} / \mathrm{ml})$ in normal subjects ${ }^{1}$

\begin{tabular}{llc}
\hline & $25-(\mathrm{OH}) \mathrm{D}$ & $24,25-(\mathrm{OH})_{2} \mathrm{D}$ \\
\hline In relation to age & & \\
$\quad<6$ days (5) & $13 \pm 4.2$ & $0.8 \pm 0.4$ \\
$2-10 \mathrm{yr}(16)$ & $15 \pm 10.4$ & $2.5 \pm 1.9$ \\
$\quad 14-17$ yr (10) & $14 \pm 6.7$ & $1.5 \pm 0.9$ \\
Adult (over 18 yr) (14) & $20 \pm 7.4$ & $1.4 \pm 0.8$ \\
In relation to season & & \\
$\quad$ January-March (14) & $15 \pm 9.1$ & $2.2 \pm 1.8$ \\
$\quad$ April-June (7) & $11 \pm 5.8$ & $2.3 \pm 1.1$ \\
July-September (5) & $21 \pm 7.4$ & $1.2 \pm 0.4$ \\
October-December (14) & $19 \pm 7.8$ & $1.4 \pm 0.7$ \\
\hline
\end{tabular}

'All values are expressed as mean \pm SD. Numbers in parentheses are numbers of different blood samples.

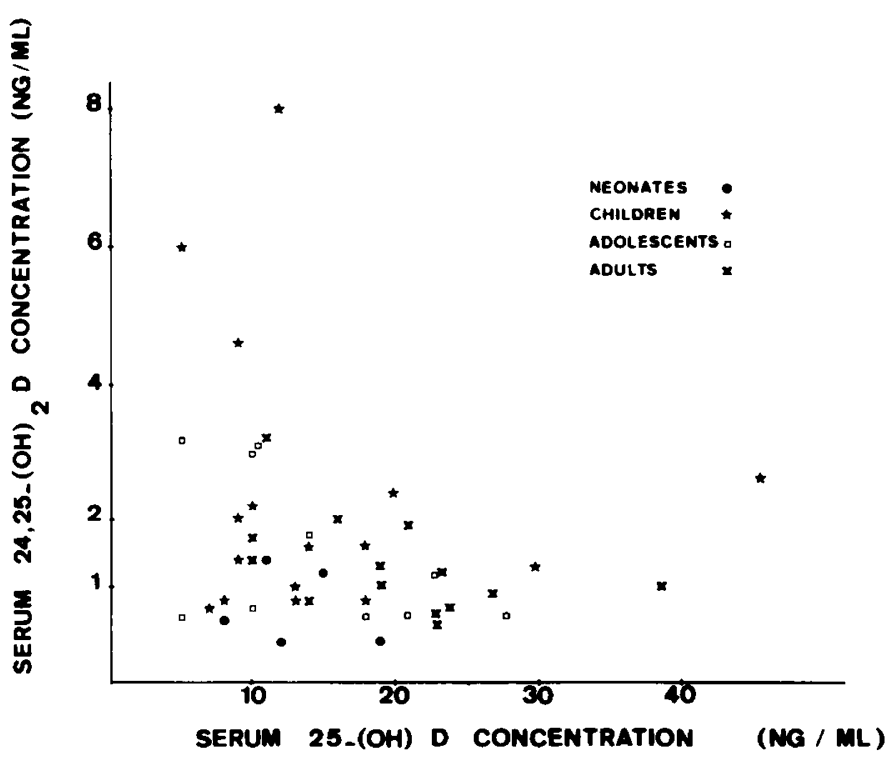

Fig. 1. Relationship between serum $24,25-(\mathrm{OH})_{2} \mathrm{D}$ concentrations and serum $25-(\mathrm{OH}) \mathrm{D}$ concentrations in normal subjects. On this figure are pooled data from 5 neonates, 16 children, 10 adolescents, and 14 adults. 
in $24,25-(\mathrm{OH})_{2} \mathrm{D}$ concentration. The ratio of serum $24,25-(\mathrm{OH})_{2} \mathrm{D} /$ $25-(\mathrm{OH}) \mathrm{D}$ concentrations increased from $4 \%$ before treatment to $52 \%$ in the 2 nd wk after vitamin $\mathrm{D}$ and calcium administration.

\section{VITAMIN D INTOXICATION}

In a 3-wk-old child referred with severe symptoms of vitamin $D_{2}$ intoxication, serum calcium concentrations had reached 14.0 $\mathrm{mg} / 100 \mathrm{ml}$. Her serum $25-(\mathrm{OH}) \mathrm{D}$ concentration was $900 \mathrm{ng} / \mathrm{ml}$ and $24,25-(\mathrm{OH})_{2} \mathrm{D}$ concentration $6 \mathrm{ng} / \mathrm{ml}$. The serum $24,25-$ $(\mathrm{OH})_{2} \mathrm{D} / 25-(\mathrm{OH}) \mathrm{D}$ ratio was $0.67 \%$.

\section{VITAMIN D RESISTANT RICKETS}

Table 3 shows the data concerning three children with "pseudodeficiency rickets" aged 11-16 yr, three subjects with hereditary hypophosphatemia aged 3-13 yr, and one patient with a vitamin D resistant rickets associated with Recklinghausen's neurofibromatosis. Pretreatment levels of $25-(\mathrm{OH}) \mathrm{D}$ and $24,25-(\mathrm{OH})_{2} \mathrm{D}$ could be measured for three patients. The presence of $24,25-(\mathrm{OH})_{2} \mathrm{D}$ was detected in the serum of the three patients (two with pseudodeficiency rickets and one with hereditary hypophosphatemia). After 3 months to $5 \mathrm{yr}$ of oral $25-(\mathrm{OH}) \mathrm{D}_{3}$ administration serum $25-(\mathrm{OH}) \mathrm{D}$ concentrations were elevated in all patients. In contrast, serum $24,25-(\mathrm{OH})_{2} \mathrm{D}$ concentrations were high in only three subjects (Table 3, patients K.A., S.K., and L.A.). These high values of $24,25-(\mathrm{OH})_{2} \mathrm{D}$ were associated with the highest values of 25 $(\mathrm{OH}) \mathrm{D}$ observed in this study, in two patients. In the third patient, it was associated with a moderately increased concentration of 25$(\mathrm{OH}) \mathrm{D}$, i.e., $98 \mathrm{ng} / \mathrm{ml}$. No correlation was found between serum $24,25-(\mathrm{OH})_{2} \mathrm{D}$ concentrations and serum calcium and phosphorus concentrations (Table 3 ).

In a fourth child with pseudo-deficiency rickets, $25-(\mathrm{OH}) \mathrm{D}$ and $24,25-(\mathrm{OH})_{2} \mathrm{D}$ serum concentrations were measured, before and during treatment with $1 \alpha$-hydroxycholecalciferol $\left(1 \alpha-(\mathrm{OH}) \mathrm{D}_{3}\right)$, over a period of $4 \mathrm{yr}$ and 6 months (Fig. 2). Serum 25-(OH)D concentrations were found most of the time in the normal range. Variations in $24,25-(\mathrm{OH})_{2} \mathrm{D}$ concentrations could not be correlated with changes in $25-(\mathrm{OH}) \mathrm{D}$ concentrations. Higher than normal values of $24,25-(\mathrm{OH})_{2} \mathrm{D}$ were observed before and in the first months after administration of the $1 \alpha-(O H) D_{3}$. Serum 24,25$(\mathrm{OH})_{2} \mathrm{D}$ concentrations were found in the normal range when biochemical and radiologic signs of rickets had disappeared. Higher than normal values were again observed when treatment had been stopped.

\section{DISCUSSION}

Recently developed methods for the measurement of 24,25 $(\mathrm{OH})_{2} \mathrm{D}$ are based on the similar potencies of $24,25-(\mathrm{OH})_{2} \mathrm{D}_{3}$ and $25-(\mathrm{OH}) \mathrm{D}_{3}$ in displacing $25-(\mathrm{OH}) \mathrm{D}_{3}$ from its binding sites in rat serum or kidney cell proteins $(4,8,10,11,12)$. 25-(OH)D competitive protein binding assays are equally sensitive for the 25 $(\mathrm{OH}) \mathrm{D}, 24,25-(\mathrm{OH})_{2}, 25,26-(\mathrm{OH})_{2}$ metabolites of cholecalciferol $(4,8,10,11)$ and of ergocalciferol (9). Therefore, the chromatography of the serum is a crucial prerequisite to the measurement of vitamin $\mathrm{D}$ metabolites. In previous methods, $24,25-(\mathrm{OH})_{2} \mathrm{D}$ was separated from $25-(\mathrm{OH}) \mathrm{D}$ on silica columns (8) or Sephadex LH 20 columns $(4,10,11,12)$. This last chromatographic technique also separates $24,25-(\mathrm{OH})_{2} \mathrm{D}$ from $25,26-(\mathrm{OH})_{2} \mathrm{D}$. All authors used a competitive protein binding assay for the measurement of 25 $(\mathrm{OH}) \mathrm{D}$ and $24,25-(\mathrm{OH})_{2} \mathrm{D}$ concentrations in serum. The smallest quantities of $24,25-(\mathrm{OH})_{2} \mathrm{D}$ (or $25-(\mathrm{OH}) \mathrm{D}$ ) detected per assay tube vary from 0.01 pmole $(8,9)$ and 0.09 pmole $(11)$, to $1.2-1.5$ pmole $(4,10)$.

The present method associates a highly sensitive assay (9) and a double step chromatography of the serum. The Sephadex LH 20 plus high pressure liquid chromatography system was aimed to avoid contamination of the $24,25-(\mathrm{OH})_{2} \mathrm{D}$ fraction by other vi-

Table 2. Serum concentrations of $25-(\mathrm{OH}) \mathrm{D}, 24,25-(\mathrm{OH})_{2} \mathrm{D}$, calcium $\left(\mathrm{Ca}_{\mathrm{s}}\right)$, and phosphorus $\left(\mathrm{Pi}_{\mathrm{s}}\right)$, in three children with vitamin $\mathrm{D}$

\begin{tabular}{lcccc} 
& \multicolumn{3}{c}{ deficiency rickets ${ }^{1}$} & \\
\hline & $25-(\mathrm{OH}) \mathrm{D}(\mathrm{ng} / \mathrm{ml})$ & $24,25-(\mathrm{OH})_{2} \mathrm{D}(\mathrm{ng} / \mathrm{ml})$ & $\mathrm{Ca}_{\mathrm{B}}(\mathrm{mg} / \mathrm{dl})$ & \\
\hline $\mathrm{D}$ deficiency rickets & & & & \\
Before treatment & $9.6 \pm 1.2^{2}$ & $0.4 \pm 0.2^{2}$ & $8.8 \pm 0.5^{2}$ & $3.8 \pm 0.9^{2}$ \\
First wk of treatment & $18.1 \pm 4.4^{2}$ & $4.2 \pm 4.3^{2}$ & $9.3 \pm 0.5^{2}$ & $4.2 \pm 1.6^{2}$ \\
Second wk of treatment & $25.5 \pm 9.2^{3}$ & $13.4 \pm 3.7^{3}$ & $9.6 \pm 0.5^{3}$ & $5.1 \pm 0.4^{3}$ \\
\hline
\end{tabular}

${ }^{1}$ All three children with overt radiologic signs of rickets received calcium supplementation before vitamin $\mathrm{D}$ treatment. $25-(\mathrm{OH}) \mathrm{D}, 24,25-(\mathrm{OH}){ }_{2} \mathrm{D}$, calcium, and phosphorus were measured 2-6 days before and in the 2 wk after one single im injection of $5 \mathrm{mg}$ vitamin $\mathrm{D}_{2}$.

${ }^{2}$ Mean \pm 1 SD of values measured in six blood samples (two samples for each child).

${ }^{3}$ Mean \pm 1 SD of values measured in three blood samples (one sample for each child).

Table 3. Serum 25-(OH)D and 24,25-(OH $)_{2}$ D concentrations $(\mathrm{ng} / \mathrm{ml})$ and corresponding serum calcium $\left(\mathrm{Ca}_{\mathrm{s}}\right)$ and phosphorus $\left(\mathrm{Pi}_{\mathrm{s}}\right)$ concentrations $(\mathrm{mg} / \mathrm{dl})$ in children with vitamin $D$ resistant rickets

\begin{tabular}{|c|c|c|c|c|c|c|c|c|c|}
\hline & \multicolumn{5}{|c|}{ Untreated } & \multicolumn{4}{|c|}{ During treatment with $25-(\mathrm{OH}) \mathrm{D}_{3}$} \\
\hline & Age $(y r)$ & $25-(\mathrm{OH}) \mathrm{D}$ & $24,25-(\mathrm{OH})_{2} \mathrm{D}$ & $\mathrm{Ca}_{8}$ & $\mathrm{Pi}_{\mathrm{s}}$ & $25-(\mathrm{OH}) \mathrm{D}$ & $24,25-(\mathrm{OH})_{2} \mathrm{D}$ & $\mathrm{Ca}_{n}$ & $\mathbf{P i}_{*}$ \\
\hline \multicolumn{10}{|c|}{ Pseudodeficiency rickets } \\
\hline K.S. & 11 & & & & & 48 & 2.4 & 7.8 & 5.5 \\
\hline K.L. & 16 & 14 & 1.6 & 5.2 & 4.6 & & & & \\
\hline \multirow[t]{4}{*}{ K.A. } & 14 & 24 & 2.5 & 6.9 & 3.9 & 90 & 2.0 & 6.3 & 4.2 \\
\hline & & & & & & 285 & 9.0 & 9.4 & 4.0 \\
\hline & & & & & & 128 & 0.8 & 9.5 & 3.4 \\
\hline & & & & & & 119 & 2.0 & 8.7 & 3.9 \\
\hline
\end{tabular}

Hereditary hypophospha-

temia

\begin{tabular}{|c|c|c|c|c|c|c|c|c|}
\hline S.K. & 13 & 12 & 1.4 & 9.9 & 1.9 & 424 & 8.2 & 10.0 \\
\hline G.M. & 13 & & & & & 61 & 2.8 & 9.2 \\
\hline L.A. & 3 & & & & & 98 & 7.7 & 10.2 \\
\hline
\end{tabular}

Vitamin D resistant rickets and neurofibromatosis 

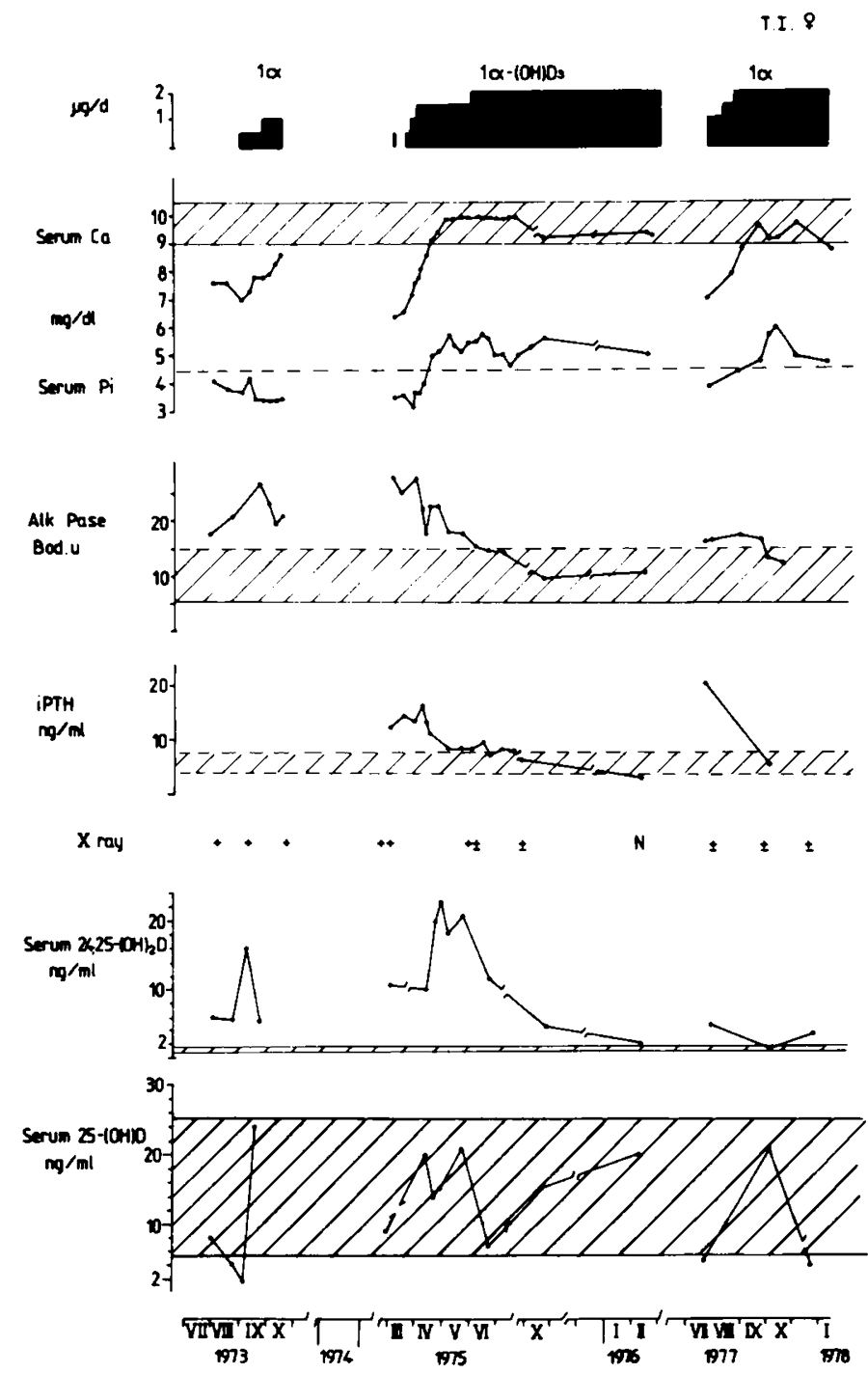

Fig. 2. Evolution of biochemical and radiologic parameters before and during administration of $1 \alpha-(\mathrm{OH})$ cholecalciferol $(0.5-2.0 \mu \mathrm{g} /$ day $)$ to a child with pseudodeficiency rickets. Serum calcium $(\mathrm{Ca})$, and phosphorus ( $\mathrm{Pi}$ ) concentrations in $\mathrm{mg} / \mathrm{dl}$, serum alkaline phosphatase activities (Alk Pase) in Bodansky units (Bod. u.), serum immunoreactive parathyroid hormone concentrations (iPTH) in $\mathrm{ng} / \mathrm{ml}$, serum $24,25-(\mathrm{OH})_{2} \mathrm{D}$ and 25 $(\mathrm{OH}) \mathrm{D}$ concentrations in $\mathrm{ng} / \mathrm{ml}$. Radiograms were normal $(\mathrm{N})$ or showed slight $( \pm)$ to moderate $(++)$ signs of rickets. Hatched areas represent for each parameter the range of normal values. The child was 7 -yr-old at the beginning of the study.

tamin D metabolites, especially when studying subjects on large vitamin $D$ therapy. With this technique, the serum $24,25-(\mathrm{OH})_{2} \mathrm{D}$ concentrations found in normal French adults are similar to those found by Taylor et al. (10) $(1.68 \pm 0.8 \mathrm{ng} / \mathrm{ml})$, by O'Riordan et al. (8) $(1.7 \mathrm{ng} / \mathrm{ml})$ in England, and by Caldas et al. (12) $(4.3 \pm 2.0$ nmole/liter i.e., $1.78 \pm 0.8 \mathrm{ng} / \mathrm{ml}$ ) in United States. They are lower than those observed in North America by Haddad et al. (4).

Our values in normal children are not significantly different from those found in normal adults. At the present time, there is only one report of serum $24,25-(\mathrm{OH})_{2} \mathrm{D}$ concentrations in children. These values are $3.3 \pm 1.3 \mathrm{ng} / \mathrm{ml}$ for $24,25-(\mathrm{OH})_{2} \mathrm{D}$ and $35.2 \pm$ $9.2 \mathrm{ng} / \mathrm{ml}$ for $25-(\mathrm{OH}) \mathrm{D}$ (11). Our data in neonates, although not statistically significant, could be in agreement with the suggestion that $24,25-(\mathrm{OH})_{2} \mathrm{D}$ serum concentrations are lower in neonates than in older children (11).

A positive correlation between serum $25-(\mathrm{OH}) \mathrm{D}$ and $24,25-$
$(\mathrm{OH})_{2} \mathrm{D}$ concentrations in normal subjects $(11,12)$ and in subjects receiving vitamin $D$ supplementation $(8,10)$ has been reported. In the present work, $24,25-(\mathrm{OH})_{2} \mathrm{D}$ serum concentrations increased when $25-(\mathrm{OH}) \mathrm{D}$ levels were elevated by vitamin $\mathrm{D}$ administration to children with vitamin $\mathrm{D}$ deficiency rickets. Yet no positive correlation was found between the serum concentrations of these two vitamin D metabolites in normal adults or in normal children. Other observations from the present study show that 24,25$(\mathrm{OH})_{2} \mathrm{D}$ serum concentration is not always correlated with 25 $(\mathrm{OH}) \mathrm{D}$ serum concentration, and suggest that regulation of the $24,25-(\mathrm{OH})_{2} \mathrm{D}$ concentration in human serum may exist: 1) after administration of high doses of vitamin $\mathrm{D}$ or $25-(\mathrm{OH}) \mathrm{D}$, higher concentrations of $24,25-(\mathrm{OH})_{2} \mathrm{D}$ in serum were not necessarily associated with greater values of serum $25-(\mathrm{OH}) \mathrm{D}$. A striking example is the finding of high $24,25-(\mathrm{OH})_{2} \mathrm{D}$ concentrations $(13.4$ $\pm 3.7 \mathrm{ng} / \mathrm{ml}$ ) a few days after vitamin $D_{2}$ administration to children with vitamin $\mathrm{D}$ deficiency rickets $(25-(\mathrm{OH}) \mathrm{D}$ serum concentration of $25.5 \pm 9.2 \mathrm{ng} / \mathrm{ml}$ ) and of similarly high 24,25 $(\mathrm{OH})_{2} \mathrm{D}$ concentration $(6 \mathrm{ng} / \mathrm{ml})$ in a child with vitamin $\mathrm{D}_{2}$ intoxication (25-(OH)D concentration of $900 \mathrm{ng} / \mathrm{ml}) .2$ ) in a child with pseudodeficiency rickets, treatment of the rachitic lesions with $1 \alpha-(\mathrm{OH}) \mathrm{D}_{3}$ was accompanied by changes in $24,25-(\mathrm{OH})_{2} \mathrm{D}$ serum concentration which could not be explained by changes in 25- $(\mathrm{OH}) \mathrm{D}$ concentration.

Finally, development of methods for the measurements of 24,25$(\mathrm{OH})_{2} \mathrm{D}$ concentration in serum should provide valuable informations for the comprehension of some pathologic states. Thus, the present results demonstrate the existence of a $25-(\mathrm{OH}) \mathrm{D}-24-$ hydroxylase in children with three types of vitamin D resistant rickets (hereditary hypophosphatemia, pseudodeficiency rickets, and vitamin D resistance associated with Recklinghausen's neurofibromatosis).

\section{REFERENCES AND NOTES}

I. Boyle, I. T., Gray, R. W., and DeLuca, H. F.: Regulation by calcium of in vivo synthesis of 1,25-dihydroxycholecalciferol and 21,25-dihydroxycholecalciferol. Proc. Nat. Acad. Sci. USA. 68: 2131 (1971)

2. Boyle, 1. T., Omdahl, J. L., Gray, R. W., and DeLuca, H. F.: The biological activity and metabolism of 24,25-dihydroxyvitamin $\mathrm{D}_{3}$. J. Biol. Chem.. 25: 4174 (1973)

3. DeLuca, H. F.: Recent advances in our understanding of the vitamin D endocrine system. J. Lab. Clin. Med., 87 : 7 (1976)

4. Haddad, J. G., Min, C., Walgate, J., and Hahn. T.: Competition by 24,25dihydroxycholecalciferol in the competitive protein binding radioassay of 25 hydroxycalciferol. J. Clin. Endocrinol. Metab., 43: 712 (1976)

5. Holick, M. F., Schnoes, H. K., and DeLuca, H. F.: Isolation and identification of 24,25-dihydroxycholecalciferol: a metabolite of vitamin $D_{3}$ made in the kidney. Biochemistry, 11: 4251 (1972)

6. Mawer, E. B., Backhouse, J., Hill, L. F., Lumb, G. A., De Silva, P., Taylor, C. M.. and Stanbury, S. W.: Vitamin D metabolism and parathyroid function in man. Clin. Sci. Molec. Med., 48: 349 (1975)

7. Omdahl, J. L., Gray, R. W., Boyle, I. T., Knutson, J., and DeLuca, H. F.: Regulation of metabolism of 25-hydroxycholecalciferol by kidney tissue in vitro by dietary calcium. Nature (New Biol.), 237: 63 (1972)

8. O'Riordan, J. L. H., Graham, R. F., and Dolev, E.: An assay for 24,25 and $25,26-$ dihydroxycholecalciferol in sera. In: Vitamin D, Biochemical, Chemical, and Clinical Aspects Related to Calcium Metabolism. Proceedings of the Third Workshop on Vitamin D, p. 519 (Walter de Gruyter, Berlin, New York, 1977)

9. Preece, M. A.. O'Riordan, J. L. H., Lawson, D. E. M., and Kodicek, E.: A competitive protein-binding assay for 25 -hydroxycholecalciferol and 25 -hydroxyergocalciferol in serum. Clin. Chim. Acta, 54: 235 (1974)

10. Taylor, C. M., Hughes, S. E.., and Da Silva. P.: Competitive protein binding assay for 24,25-dihydroxycholecalciferol. Biochem. Biophys. Res. Comm., 70: 1243 (1976)

11. Weisman, Y., Reiter, E., and Root, A.: Measurement of 24,25-dihydroxyvitamin $D$ in sera of neonates and children. J. Pediatr., 91: 904 (1977)

12. Caldas, A. E., Gray, R. W., and Lemann, J., Jr.: The simultaneous measurement of vitamin D metabolites in plasma: studies in healthy adults and in patients with calcium nephrolithiasis. J. Lab. Clin. Med., 91: 840 (1978)

13. The authors thank Dr. J. L. H. O'Riordan (London, U.K.) for helpful discussions that led to the development of their $24.25-(\mathrm{OH})_{2} \mathrm{D}_{3}$ assay. Our grateful thanks, also, to Dr. M. Uskokovic (Hoffman-La Roche, Nutley, New Jersey, USA) and the Roussel Laboratory (Paris, France) for providing the synthetic vitamin D metabolites.

14. This research was supported, in part, by grant 7770668 from the D.G.R.S.T

15. Received for publication March 28, 1978.

16. Accepted for publication August 30, 1978. 